\title{
Intravenous Use of Lemon Juice with Brown Sugar: A Potentially Fatal Cook-Up Technique?
}

Sir,

Several cook-up techniques exist for psychoactive substance users. Opioid and cocaine are two common psychoactive substances where cook-up techniques are most frequently used. Although recent reports have documented purposive use of lemon juice among crack cocaine users with its adverse effects (e.g., candidal endophthalmitis and disseminated candidiasis), reports of the use of the same in opioid dependence are sparse. ${ }^{[1-6]}$ Index patient, a 25-year-old Hindu male visited the outpatient department of center for addiction psychiatry unit at our institute with chief complaints of intake of cannabis for 7 years, intake of brown sugar for 
5 years. History of the present illness revealed a regular pattern of use of all the substances reported in chief complaints, in dependent manner. On detailed history, it was found that till 2 months back, instead of chasing ("chasing the dragon tail"), he was using intravenous preparation of brown sugar after mixing with syrup pheniramine $(15 \mathrm{~m} / \mathrm{ml})$, with a proportion of $0.1 \mathrm{~g}$ of brown sugar in $10 \mathrm{ml}$ of syrup pheniramine. By this time, he got to know from a friend about the use of lemon juice along with brown sugar. He used to prepare a mixture of $0.1 \mathrm{~g}$ of brown sugar, $10 \mathrm{ml}$ of pheniramine, and 10 drops of lemon juice by boiling properly. When he used the above mixture intravenously for the first time, he felt an "extra high." Until 2 months back he was using nearly $20 \mathrm{ml}$ of the above mixture per day through $8-10$ occasions. According to him, he started to experience extra pleasure thank before after mixing with lemon juice, and he would feel more energetic. He left taking cannabis and syrup pheniramine, and he was taking brown sugar mixing with lemon juice and taking intravenously for the past 2 months preceding his visit at our outpatient department. His average requirement of brown sugar started to decrease around this period. However, he continued to get a similar "extra high" than before, and his daily average intake of brown sugar remained reduced than before. Routine biochemical and hematological investigation did not reveal any abnormality. Detoxification was done with the help of tab. Buprenorphine $2 \mathrm{mg}+$ naloxone $0.5 \mathrm{mg}$, thrice daily which was titrated down to twice daily after 10 days. He had been offered psychotherapy and underwent motivational enhancement therapy.

Index patient experienced "extra high" and his pattern of intake of brown sugar changed further after he started cooking up with lemon juice. His daily requirement of brown sugar had been decreased, and he left taking cannabis and syrup pheniramine which he used to take for years. However, he continued to get similar "extra high" than he used to get before he started to "cook up" with lemon juice. This suggests that the psychoactive effect of brown sugar was altered by lemon juice. There are reports of similar effects in literature for grapefruit juice. Reports have shown that grapefruit juice (Citrus Paradisi) does increase pharmacological effects of opioid related substances such as morphine and oxycodone by inhibiting first-pass metabolism of oxycodone by cytochrome P450 3A4 (CYP3A4) thereby increasing the concentration of oxymorphone. ${ }^{[7-9]}$ Similarly, grapefruit juice modestly increased methadone bioavailability among patients on methadone maintenance treatment where the similar effect on CYP3A4 enzyme was thought to be mediating. ${ }^{[7]}$ Thus, intake of grapefruit juice together with opioid has been found to have the potential to precipitate opioid overdose in a person with opioid dependence syndrome. Citric acid which is common in both lemon juice $(48 \mathrm{~g} / \mathrm{L})^{[10]}$ and grapefruit juice $(25 \mathrm{~g} / \mathrm{L})^{[10]}$ might be responsible for this. However, grapefruit juice has been proposed to inhibit only intestinal CYP3A as it had no effect on the CYP3A substrates when given intravenously. ${ }^{[9,10]}$ Although lemon juice was mixed with an intravenous preparation of brown sugar, whether similar effect of citric acid on CYP3A4 from lemon juice could occur was not clear and could be ruled out neither. Based on available research evidence, we hypothesize that lemon juice had potentiated effect of brown sugar by altering pharmacokinetics of the later. Considering the adverse effects mentioned above, more research on how these fruit juices including lemon juice exert their effect on other psychoactive properties of opioid and mode of intake and related psychoactive substances across routes of administration should be carried out to prevent any unwarranted or accidental fatalities.

\section{Declaration of patient consent}

The authors certify that they have obtained all appropriate patient consent forms. In the form the patient(s) has/have given his/her/their consent for his/ her/their images and other clinical information to be reported in the journal. The patients understand that their names and initials will not be published and due efforts will be made to conceal their identity, but anonymity cannot be guaranteed.

\section{Financial support and sponsorship}

Nil.

\section{Conflicts of interest}

There are no conflicts of interest.

\section{Sourav Khanra, Amiya Krushna Sahu, Christoday Raja Jayant Khess}

S. S. Raju Centre for Addiction Psychiatry, Central Institute of Psychiatry, Ranchi, Jharkhand, India

Address for correspondence: Dr. Sourav Khanra, Room No. 4, New Teaching Block, S. S. Raju Centre for Addiction Psychiatry, Central Institute of Psychiatry, Ranchi - 834 006, Jharkhand, India. E-mail: psyksk.cip@gmail.com

\section{REFERENCES}

1. Strang J, Keaney F, Butterworth G, Noble A, Best D. Different forms of heroin and their relationship to cook-up techniques: Data on, and explanation of, use of lemon juice and other acids. Subst Use Misuse 2001;36:573-88.

2. Newton-John HF, Wise K, Looke DF. Role of the lemon in disseminated candidiasis of heroin abusers. Med J Aust 1984;140:780-1. 
3. Servant JB, Dutton GN, Ong-Tone L, Barrie T, Davey C. Candidal endophthalmitis in Glaswegian heroin addicts: Report of an epidemic. Trans Ophthalmol Soc U K 1985;104(Pt 3):297-308.

4. Waninger KN, Gotsch PB, Watts D, Thuahnai ST. Use of lemon juice to increase crack cocaine solubility for intravenous use. J Emerg Med 2008;34:207-9.

5. Albini TA, Sun RL, Holz ER, Khurana RN, Rao NA. Lemon juice and candida endophthalmitis in crack-cocaine misuse. Br J Ophthalmol 2007;91:702-3.

6. Welsh JW, Rodriquez C, Suzuki J. Bilateral upper extremity cellulitis from injecting crack cocaine dissolved in lemon juice: A case report. Prim Care Companion CNS Disord 2016;18. doi: 10.4088/PCC.16I01933.

7. Benmebarek M, Devaud C, Gex-Fabry M, Powell Golay K, Brogli C, Baumann $\mathrm{P}$, et al. Effects of grapefruit juice on the pharmacokinetics of the enantiomers of methadone. Clin Pharmacol Ther 2004;76:55-63.

8. Okura T, Ozawa T, Ito Y, Kimura M, Kagawa Y, Yamada S, et al. Enhancement by grapefruit juice of morphine antinociception. Biol Pharm Bull 2008;31:2338-41.

9. Nieminen TH, Hagelberg NM, Saari TI, Neuvonen M, Neuvonen PJ, Laine $\mathrm{K}$, et al. Grapefruit juice enhances the exposure to oral oxycodone. Basic Clin Pharmacol Toxicol 2010;107:782-8.
10. Penniston KL, Nakada SY, Holmes RP, Assimos DG Quantitative assessment of citric acid in lemon juice, lime juice, and commercially-available fruit juice products. J Endourol 2008;22:567-70.

This is an open access journal, and articles are distributed under the terms of the Creative Commons Attribution-NonCommercial-ShareAlike 4.0 License, which allows others to remix, tweak, and build upon the work non-commercially, as long as appropriate credit is given and the new creations are licensed under the identical terms.

\begin{tabular}{|l|l|}
\hline \multicolumn{2}{|c|}{ Access this article online } \\
\hline Quick Response Code: & Website: \\
\hline
\end{tabular}

How to cite this article: Khanra S, Sahu AK, Khess CR. Intravenous use of lemon juice with brown sugar: A potentially fatal cook-up technique? J Neurosci Rural Pract 2019;10:386-8.

C 2019 Journal of Neurosciences in Rural Practice | Published by Wolters Kluwer - Medknow 